\title{
Effect of hyperthermia on the replication of white spot syndrome virus (WSSV) in Procambarus clarkii
}

\author{
Hua-Hua Du, Wei-Fen Li, Zi-Rong Xu*, Zong-Su Kil \\ Key Laboratory of Molecular Animal Nutrition, Ministry of Education, Feed Science Institute, Zhejiang University, \\ Hangzhou 310029, PR China
}

\begin{abstract}
The effect of hyperthermia on the development of white spot syndrome virus (WSSV) in the crayfish Procambarus clarkii was studied by competitive PCR. Crayfish were exposed to different temperatures $\left(24 \pm 1\right.$ and $\left.32 \pm 1^{\circ} \mathrm{C}\right)$ after WSSV injection. No mortality was observed when crayfish were held at $32 \pm 1^{\circ} \mathrm{C}$, but mortality reached $100 \%$ when crayfish were transferred to $24 \pm 1^{\circ} \mathrm{C}$. Competitive PCR showed that viral levels at $32 \pm 1^{\circ} \mathrm{C}$ remained at $10^{5}$ copies $\mathrm{mg}^{-1}$ tissue, while at $24 \pm 1^{\circ} \mathrm{C}$ levels were significantly higher, rising from $10^{4}$ to $10^{10} \mathrm{copies} \mathrm{mg}^{-1}$ tissue. These results suggest that hyperthermia reduces viral replication, but does not eliminate viral particles from WSSV-infected crayfish.
\end{abstract}

KEY WORDS: White spot syndrome virus - Hyperthermia - Viral replication - Procambarus clarkii · Competitive PCR · Water temperature

\section{INTRODUCTION}

White spot syndrome virus (WSSV) is the aetiological agent of white spot disease (WSD), which continues to cause severe mortalities among cultured shrimp worldwide. The virus can also infect other decapod crustacean species (Lo et al. 1996). Therefore, WSSV is not only a major threat to the shrimp industry, but also to the marine environment.

Temperature is one of the most important environmental factors affecting outbreaks of WSD, because it can influence shrimp metabolism, oxygen consumption, growth rate, molt cycle, and survival rate directly. Both hyperthermia and hypothermia have been reported to protect shrimp (Litopenaeus vannamei also called Penaeus vannamei) from WSD after challenge with WSSV (Vidal et al. 2001, Guan et al. 2003). Since both hypothermic and hyperthermic shrimp infected with WSSV can develop WSD with $100 \%$ mortality when transferred to ambient temperature, it has been suggested that the protective effect is not attributable to viral inactivation (Vidal et al. 2001, Jiravanichpaisal et al. 2004). However, the way in which hyperthermia affects the viral infection has not yet been determined.

The present study was carried out to examine the effect of hyperthermia on viral replication and the progress of WSD in the freshwater crayfish Procambarus clarkii.

\section{MATERIALS AND METHODS}

Crayfish culture. Procambarus clarkii crayfish, approximately 20 to $25 \mathrm{~g}$ and 8 to $10 \mathrm{~cm}$ each, were reared at $24 \pm 1{ }^{\circ} \mathrm{C}$. They were kept in tanks with sandfiltered, ozone-treated, and flow-through freshwater and fed with commercial pellet feed at $5 \%$ of body weight per day. Gill tissues from randomly selected 
individuals were subjected to PCR assays using WSSV334F/R primers, to ensure that the crayfish were WSSV-free before experimental infection.

WSSV stock and dose for crayfish challenge. The virus originated from WSSV-infected penaeid shrimp (Penaeus chinensis, also called Fenneropenaeus chinensis) from Ningbo (Zhejiang, East China Sea), China, in 2001. The WSSV stock was generated in crayfish Procambarus clarkii and purified from gill tissues by sucrose gradient centrifugation as described by Van Hulten et al. (2001b). It was stored at $-80^{\circ} \mathrm{C}$.

The WSSV stock was serially diluted to prepare solutions containing various target copy numbers determined by competitive PCR as described below. Subsequently, the WSSV solutions with different copy numbers (i.e. $10^{4}, 10^{5}, 10^{6}, 10^{7}, 10^{8}$, and $10^{9}$ ), as well as the negative control $(330 \mathrm{mM} \mathrm{NaCl})$, were injected intramuscularly into healthy crayfish in the lateral area of the fourth abdominal segment at $0.1 \mathrm{ml}$ shrimp $^{-1}$. For these tests, there were 10 crayfish in each experimental group. During the experiment, crayfish mortality was monitored twice daily, and dead crayfish were examined by PCR to confirm WSSV infection.

Effect of water temperatures on WSSV infectivity. Prior to WSSV challenge, the crayfish were acclimated to the desired temperatures $\left(24 \pm 1\right.$ and $32 \pm 1^{\circ} \mathrm{C}$ ) for $1 \mathrm{wk}$. For these experiments, there were 14 crayfish in each group and each crayfish was injected intramuscularly with $0.1 \mathrm{ml}$ of WSSV stock dilution containing $10^{6}$ viral copies. At the same time, control crayfish were injected with $0.1 \mathrm{ml}$ of $330 \mathrm{mM} \mathrm{NaCl}$. The number of dead crayfish was recorded, and cumulative mortality was calculated for each group. After $12 \mathrm{~d}$, the group at $32 \pm 1^{\circ} \mathrm{C}$ was transferred to $24 \pm 1^{\circ} \mathrm{C}$ and survival rates were monitored. Samples of freshly dead crayfish were tested for WSSV by PCR.

To monitor WSSV replication, 2 additional groups of crayfish at $24 \pm 1$ and $32 \pm 1^{\circ} \mathrm{C}$ (15 crayfish each) were challenged with WSSV as described above. At various times after injection $(12,24,48,72$, and 96 h), 3 crayfish were removed from each group and subjected to PCR analysis.

Construction of a competitive internal standard for WSSV. The WSSV primers (WSSV334F/R) used in this study were chosen from sequence data of VP28 (Van Hulten et al. 2001a). The primers amplified a 334 bp amplicon from the WSSV genome. The sequence of primer WSSV334F is 5' CTT TCA CTC TTT CGG TCG TG $3^{\prime}$ and that of primer WSSV334R is 5' TTC TGC CCC ACA GTC ACT TC 3'. A WSSV DNA competitor that was $54 \mathrm{bp}$ shorter than the $334 \mathrm{bp}$ amplicon was prepared so that it could be amplified by the same primers (Celi et al. 1993). This 280 bp DNA fragment was cloned into pUcm-T easy vector (Promega) in accordance with standard procedures. The recombinant plasmid was sequenced and shown to contain only 1 copy of the insert with WSSV334F and WSSV334R at each end. The recombinant plasmid was purified, quantified spectrophotometrically, and serially diluted with double-distilled $\mathrm{H}_{2} \mathrm{O}$ for use as an internal standard in the competitive PCR (Tang \& Lightner 2000).

WSSV detection and quantitative analysis by PCR. Total DNA was extracted from gill tissues of crayfish with an animal tissue genomic DNA mini-prep kit (Vgene). PCR was performed with the WSSV334F/R primers using the following protocol: $5 \mathrm{~min}$ at $94^{\circ} \mathrm{C}$ followed by 35 cycles at $94^{\circ} \mathrm{C}$ for $40 \mathrm{~s}, 55^{\circ} \mathrm{C}$ for $50 \mathrm{~s}$, and $72^{\circ} \mathrm{C}$ for $1 \mathrm{~min}$. For competitive PCR, aliquots from a 10 -fold serial dilution of the internal standard plasmid (ISP) were added in equal volume with the DNA template to the PCR reaction solution for PCR amplification as described above. The PCR products were analyzed by electrophoresis on $2 \%$ agarose gels stained with ethidium bromide and visualized by ultraviolet transillumination.

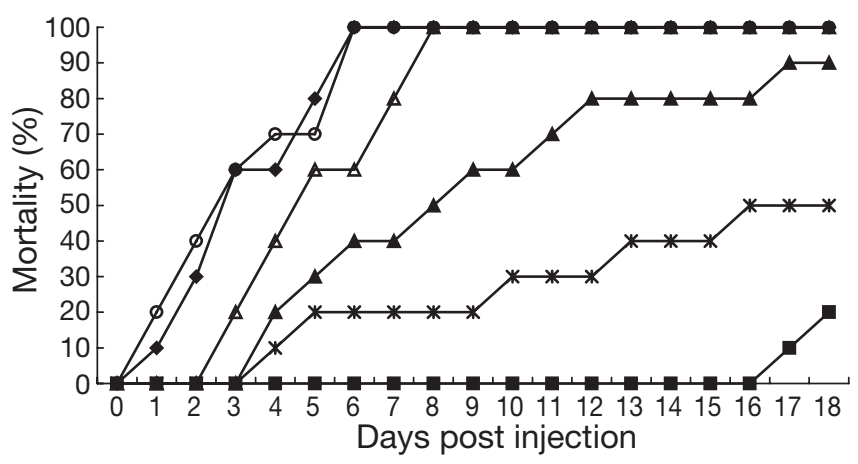

Fig. 1. Procambarus clarkii. In vivo white spot syndrome virus (WSSV) titration in crayfish. Different copy numbers of WSSV $\left(\bullet: 10^{9} ;\right.$ O: $\left.10^{8}{ }_{i} \Delta: 10^{7} ; \mathbf{\Delta}: 10^{6} ; \boldsymbol{*}: 10^{5} ; \mathbf{\square}: 10^{4}\right)$ were injected

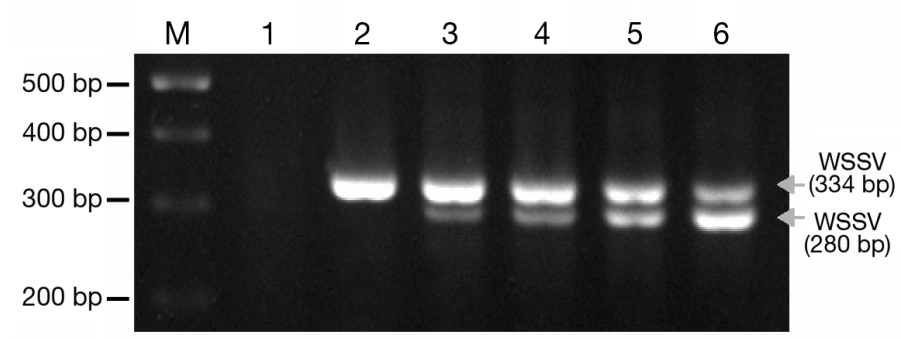

Fig. 2. Procambarus clarkii. Determination of WSSV DNA copy number in gills collected from WSSV-infected crayfish (Lane M: marker; Lane 1: un-infected crayfish [no DNA template]; Lane 2: DNA template from WSSV-infected crayfish alone; Lanes 3 to 6: 2 -fold serial dilutions [3.3 $\times 10^{9}$ copies in Lane 6 to $4.2 \times 10^{8}$ copies in Lane 3] of internal standard for co-amplification with WSSV DNA) 


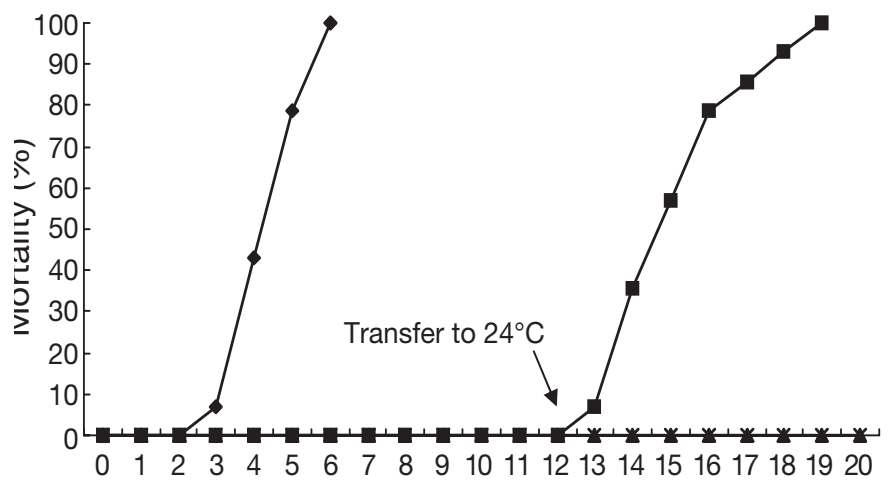

Days post challenge

$$
\begin{array}{ll}
\rightarrow \text { Injection } 24^{\circ} \mathrm{C} & \rightarrow \text { Injection } 32^{\circ} \mathrm{C} \\
\rightarrow \text { Control } 24^{\circ} \mathrm{C} & * \text { Control } 32^{\circ} \mathrm{C}
\end{array}
$$

Fig. 3. Procambarus clarkii. Mortality of crayfish held at 2 different temperatures after intramuscular injection of WSSV

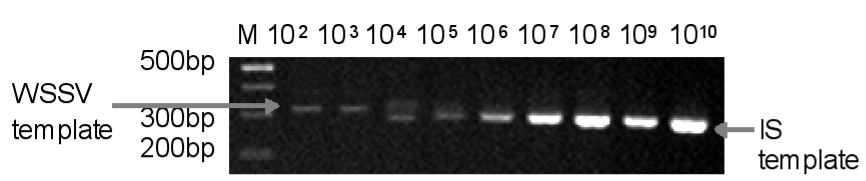

$12 \mathrm{~h}$ post injection at $24^{\circ} \mathrm{C}$

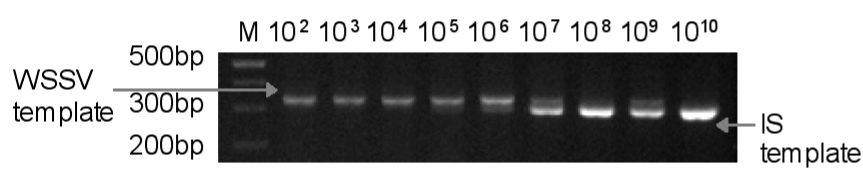

$24 \mathrm{~h}$ post injection at $24^{\circ} \mathrm{C}$

$\mathrm{M} 10^{2} 10^{3} 10^{4} 10^{5} 10^{6} 10^{7} 10^{8} 10^{9} 10^{10}$

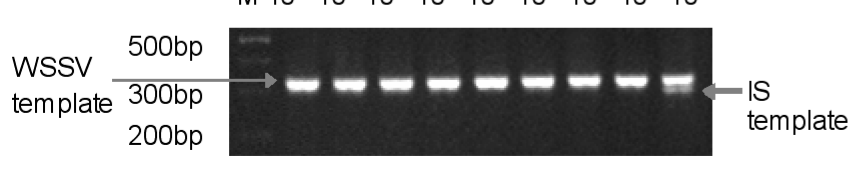

$48 \mathrm{~h}$ post injection at $24^{\circ} \mathrm{C}$

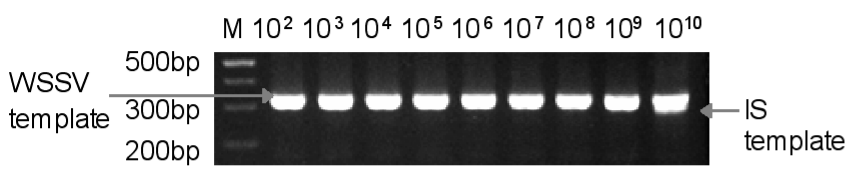

$72 \mathrm{~h}$ post injection at $24^{\circ} \mathrm{C}$

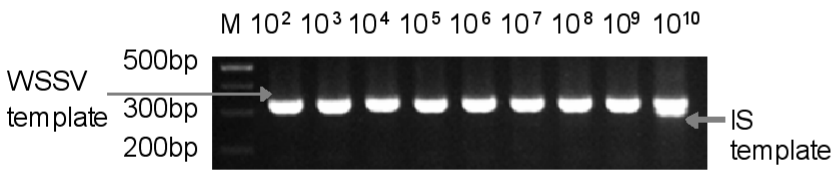

$96 \mathrm{~h}$ post injection at $24^{\circ} \mathrm{C}$

\section{RESULTS AND DISCUSSION}

In vivo virus titration to determine the dilution resulting in $100 \%$ mortality in Procambarus clarkii crayfish indicated that WSSV stock containing $10^{6}$ copies was sufficient, and this was used in subsequent experiments (Fig. 1).

After preliminary estimation of target template numbers using 10 -fold serial dilutions ( $10^{3}$ to $10^{10}$ copies) of ISP, we used 2-fold serial dilutions of ISP amplified together with constant aliquots $(1 \mu \mathrm{l})$ of genome DNA to yield 2 bands (i.e. a larger amplicon of $334 \mathrm{bp}$ from the WSSV genome and a smaller amplicon of $280 \mathrm{bp}$ from the ISP) (Fig. 2). The WSSV amplicon concentration progressively increased as the concentration of the ISP decreased, confirming that the ISP target competed with the WSSV genome DNA target.

At $24 \pm 1{ }^{\circ} \mathrm{C}$ crayfish showed $100 \%$ mortality by Day 6 post-injection of WSSV, whereas no mortality was

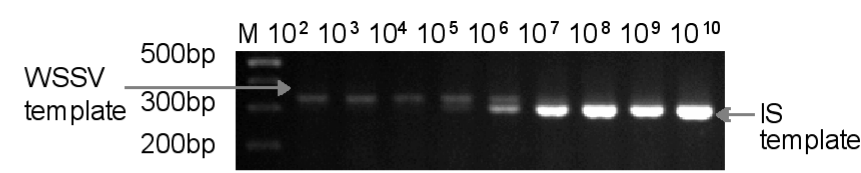

$12 \mathrm{~h}$ post injection at $32^{\circ} \mathrm{C}$

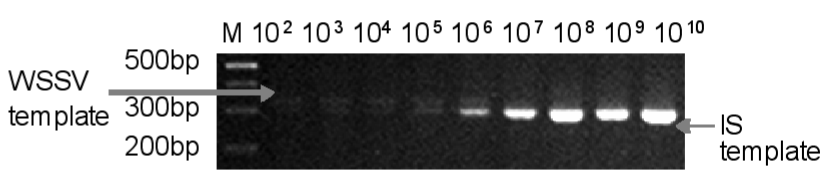

$24 \mathrm{~h}$ post injection at $32^{\circ} \mathrm{C}$

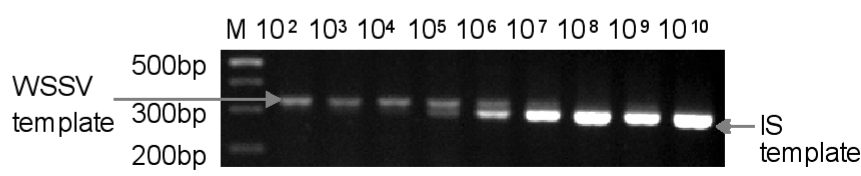

$48 \mathrm{~h}$ post injection at $32^{\circ} \mathrm{C}$

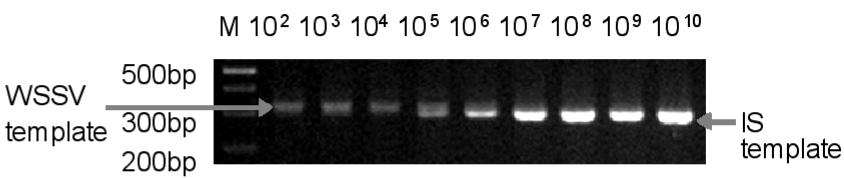

$72 \mathrm{~h}$ post injection at $32^{\circ} \mathrm{C}$

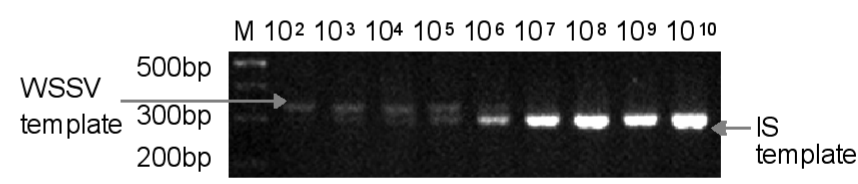

$96 \mathrm{~h}$ post injection at $32^{\circ} \mathrm{C}$

Fig. 4. Procambarus clarkii. Competitive PCR of WSSV in gills (Lane M: DNA marker). Numbers indicate WSSV copies. Left column: crayfish held at $24^{\circ} \mathrm{C}$; right column: crayfish held at $32^{\circ} \mathrm{C}$. IS: Internal Standard 
observed at $32 \pm 1^{\circ} \mathrm{C}$. The crayfish that did not die from WSD during the $12 \mathrm{~d}$ after WSSV injection were transferred to tanks at $24 \pm 1{ }^{\circ} \mathrm{C}$. Mortality started immediately the next day and reached $100 \%$ within $7 \mathrm{~d}$ (Fig. 3). Vidal et al. (2001) reported similar results for WSSV infection in Litopenaeus vannamei. This mortality pattern indicated that, despite a healthy appearance, incubation at $32 \pm 1^{\circ} \mathrm{C}$ did not result in elimination of WSSV from the crayfish.

To determine whether hyperthermia affected viral replication, competitive PCR was carried out using the gills of Procambarus clarkii taken at various times after WSSV injection. At $24 \pm 1{ }^{\circ} \mathrm{C}$, there were approximately $10^{4}$ virions $\mathrm{mg}^{-1}$ gill tissue at $12 \mathrm{~h}$ post-injection and $>10^{6}$ copies at $24 \mathrm{~h}$ post-injection. This reached about $10^{10}$ copies at $48 \mathrm{~h}$ post-injection. However, at 32 $\pm 1{ }^{\circ} \mathrm{C}$, there were approximately $10^{5}$ copies $\mathrm{mg}^{-1}$ tissue at $12 \mathrm{~h}$ post-injection, and this level remained almost the same even up to $96 \mathrm{~h}$ post-injection (Fig. 4). This result corresponded with that in the initial challenge experiment (Fig. 3). Results suggested that hyperthermia could reduce viral replication, but the mechanisms for this beneficial effect of hyperthermia were not determined. Granja et al. (2003) suggested that hyperthermia might facilitate apoptosis in WSSV-infected Litopenaeus vannamei and might be one of the mechanisms responsible for increased survival of infected shrimp maintained at $32^{\circ} \mathrm{C}$. On the other hand, water temperature might have an effect on the immune response of the host (Watson et al. 1998, Jiravanichpaisal et al. 2004). In addition, hyperthermia might affect several steps in viral replication, including absorption, synthesis of large molecules (e.g. proteins and nucleic acids), enzyme activity, and uncoating (Guan et al. 2003). Thus, further study is needed to determine the mechanisms.

Editorial responsibility: Timothy W. Flegel, Bangkok, Thailand
Acknowledgements. We thank C. X. Hu and J. T. Yao from Feed Science Institute, Zhejiang University, for their valuable assistance in laboratory work.

\section{LITERATURE CITED}

Celi FS, Zenilman ME, Shuldiner AR (1993) A rapid and versatile method to synthesize internal standards for competitive PCR. Nucleic Acids Res 21:1047

Granja CB, Aranguren LF, Vidal OM, Aragon L, Salazar M (2003) Does hyperthermia increase apoptosis in white spot syndrome virus (WSSV)-infected Litopenaeus vannamei? Dis Aquat Org 54:73-78

Guan Y, Yu Z, Li C (2003) The effect of temperature on white spot syndrome infections in Marsupenaeus japonicus. J Invertebr Pathol 83:257-260

Jiravanichpaisal P, Soderhall K, Soderhall I (2004) Effect of water temperature on the immune response and infectivity pattern of white spot syndrome virus (WSSV) in freshwater crayfish. Fish Shellfish Immunol 17:265-275

Lo C, Ho C, Peng S, Chen C and 7 others (1996) White spot syndrome baculovirus (WSBV) detected in cultured and captured shrimp, crabs and other arthropods. Dis Aquat Org 27:215-225

Tang KFJ, Lightner DV (2000) Quantification of white spot syndrome virus DNA through a competitive polymerase chain reaction. Aquaculture 189:11-21

Van Hulten MCW, Witteveldt J, Peters S, Kloosterboer N and 5 others (2001a) The white spot syndrome virus DNA genome sequence. Virology 286:7-22

Van Hulten MCW, Witteveldt J, Snippe M, Vlak JM (2001b) White spot syndrome virus envelop protein VP28 is involved in the systemic infection of shrimp. Virology 285:228-233

Vidal OM, Granja CB, Aranguren F, Brock JA, Salazar M (2001) A profound effect of hyperthermia on survival of Litopenaeus vannamei juveniles infected with white spot syndrome virus. J World Aquacult Soc 32:364-372

Watson LR, Milani A, Hedrick RP (1998) Effects of water temperature on experimentally-induced infections of juvenile white sturgeon (Acipenser transmontanus) with the white sturgeon iridovirus (WSIV). Aquaculture 166: $213-228$

Submitted: December 5, 2005; Accepted: March 29, 2006

Proofs received from author(s): July 10, 2006 